\title{
ALIH KODE (CODE-SWITCHING) PADA JEJARING SOSIAL PATH
}

\author{
Rosdiana \\ Program Studi Teknik Informatika, Universitas Indraprasta PGRI \\ Email: rosdianasidik.rs@gmail.com
}

\begin{abstract}
Abstrak
Alih kode, perubahan kode dalam penggunaan bahasa merupakan fenomena bahasa dalam masyarakat bilingual atau multibahasa. Pesatnya perkembangan teknologi menyebabkan banyak perubahan bahasa juga terjadi di internet termasuk situs jejaring sosial seperti Path. Penelitian ini adalah tentang bagaimana alih kode dari Bahasa Indonesia ke Bahasa Inggris ditunjukkan pada jejaring sosial Path. Penelitian ini berfokus pada jenis alih kode, pola bahasa, tema, dan fungsi alih kode. Data kode- beralih statusnya jalan dianalisis dengan teori alih kode oleh Poplack (1980), Gumperz (1982), dan Romaine (2000). Penelitian ini merupakan penelitian deskriptif kualitatif. Hasilnya menunjukkan jenis alih kode di Path saling sentential dan intra beralih sentensial. Kedua jenis alih kode disajikan dalam katakata, frasa, dan kalimat. Alih kode pada kata adalah kata benda, kata sifat, kata keterangan, dan kata kerja. Frasa dalam kode-switching kata benda, kata sifat, adverbial, dan frase preposisional. Sedangkan alih kode kalimat yang ditemukan di Path tunggal, majemuk, dan kalimat kompleks. Tema dalam alih kode pada Path mencakup tema yang berkaitan dengan kehidupan sosial, akademik, dan pribadi dari pengguna bahasa. Fungsi alih kode dalam status dianalisis adalah untuk mengekspresikan emosi dan makna tertentu, untuk memaksakan makna tertentu, dan untuk menunjukkan identitas bahasa pengguna.
\end{abstract}

Kata Kunci: Alih Kode, Jenis Alih Kode, Fungsi Alih Kode, Tema Alih Kode, Path.

\section{Pendahuluan}

Globalisasi berimbas pada berbagai aspek kehidupan manusia termasuk penggunaan bahasa. Jika sebelumnya proses pertukaran dan pencampuran bahasa terjadi karena datangnya sekelompok penutur bahasa ke suatu daerah yang menggunakan bahasa yang berbeda dengan bahasa yang digunakan oleh bahasa pendatang, maka saat ini kedatangan fisik bukan merupakan faktor utama yang menyebabkan pertukaran atau pencampuran bahasa. Interaksi antar pengguna bahasa terjadi melalui dunia maya atau internet, yang saat ini mengalami peningkatan yang sangat pesat. Fenomena globalisasi ini membuat jumlah penutur bahasa yang menguasai lebih dari satu bahasa meningkat secara signifikan. Hal ini menunjukkan adanya bilingualisme (kedwibahasaan) atau multilingualisme (berbahasa banyak) yang semakin meluas.

Fenomena kedwibahasaan ini juga terjadi pada kaum muda atau anak-anak di usia remaja. Selain itu, globalisasi semakin mengukuhkan bahasa Inggris sebagai bahasa Internasional. Bahasa Inggris yang sebelumnya memang sudah merupakan bahasa pergaulan Internasional, saat ini menjadi bahasa yang paling banyak digunakan di dunia termasuk di dunia maya. Crystal (2003) dalam bukunya Global English, menyatakan bahwa Bahasa Inggris hingga saat ini masih menempati posisi sebagai bahasa yang paling banyak digunakan di dunia dalam berbagai aspek termasuk di internet. Situs jejaring sosial merupakan suatu fenomena yang berkembang dengan sangat pesat di dunia maya. Path merupakan salah satu situs jejaring sosial yang paling banyak memiliki pengguna di Indonesia. Banyaknya jumlah pengguna Path menyebabkan banyaknya fenomena kebahasaan yang dapat diamati termasuk alih kode (code-switching). Penelitian ini difokuskan pada jenis alih kode yang muncul, tema yang muncul dalam alih kode dan fungsi penggunaan alih kode.

Berdasarkan latar belakang masalah, maka penulis dapat menuliskan fokus dan subfokus penelitian. Fokus penelitian difokuskan pada penggunaaan kebahasaan yang diamati yaitu alih kode (switch-code) pada pengguna jejaring sosial Path. Dikarenakan Path merupakan 
salah satu situs jejaring sosial yang paling banyak memiliki pengguna di Indonesia. Sedangkan subfokus penelitian terbagi pada: (a) jenis alih kode yang muncul, (b) tema yang muncul dalam alih kode, dan (c) fungsi penggunaan alih kode.

\section{Tinjauan Pustaka}

\section{Alih Kode (Code- Switching)}

Alih kode (code switching) adalah peristiwa peralihan dari satu kode ke kode yang lain. Misalnya penutur menggunakan bahasa Indonesia beralih menggunakan bahasa Jawa. Alih kode merupakan salah satu aspek ketergantungan bahasa (language dependency) dalam masyarakat multilingual. Dalam masyarakat multilingual sangat sulit seorang penutur mutlak hanya menggunakan satu bahasa.

Nilep (2006) berpendapat bahwa "code switching is a practice of parties in discourse to signal changes in context by using alternate grammatical systems or subsystems, or codes." Pendapat tersebut dapat didefinisikan bahwa alih kode terjadi apabila pembicara bergeser bahasanya dari satu bahasa ke bahasa lain dalam ujarannya. Alih kode terjadi pada dasarnya antara kalimat.

Ohoiwutun (2007) mengatakan alih kode (code switching), yakni peralihan pemakaian dari suatu bahasa atau dialek ke bahasa atau dialek lainnya. Alih bahasa ini sepenuhnya terjadi karena perubahan-perubahan sosiokultural dalam situasi berbahasa. Perubahan-perubahan yang dimaksud meliputi faktor-faktor seperti hubungan antara pembicara dan pendengar, variasi bahasa, tujuan berbicara, topik yang dibahas, waktu dan tempat berbincang. Lebih lanjut Apple (dalam Chaer dan Agustina, 2004) mengatakan bahwa alih kode yaitu gejala peralihan pemakaian bahasa karena berubahnya situasi.

Ditambahkan oleh Romaine (dalam Nilep, 2006), "the definition of metaphorical switching relies on the use of two language varieties within a single social setting". Sehingga dapat dikatakan bahwa alih kode dapat didefinisikan sebagai penggunaan lebih dari satu bahasa, variasi, atau gaya oleh pembicara dalam suatu ucapan atau wacana, atau antara lawan bicara atau situasi yang berbeda.

Alih kode merupakan salah satu aspek ketergantungan bahasa dalam masyarakat multilingual. Dalam masyarakat multilingual sangat sulit seorang penutur menggunakan satu bahasa karena kita ketahui bahwa dalam suatu masyarakat terdapat lebih dari satu suku. Dalam alih kode masing-masing bahasa masih cenderung mendukung fungsi masing-masing dan masing-masing fungsi sesuai dengan konteksnya. Sedangkan Hymes (2003) menyatakan bahwa alih kode itu bukan hanya terjadi antar bahasa tetapi juga antar ragam bahasa atau gaya-gaya yang terjadi dalam suatu bahasa.

Sebagai contoh peristiwa peralihan yang terjadi dalam suatu kelas yang sedang mempelajari bahasa asing (sebagai contoh bahasa Inggris). Di dalam kelas tersebut secara otomatis menggunakan dua bahasa yaitu bahasa Indonesia dan bahasa Inggris. Kemudian terjadi percakapan dalam suatu bahasa nasional (contoh bahasa Indonesia) lalu tiba-tiba beralih ke bahasa daerah (contoh bahasa Sumbawa), maka kedua jenis peralihan ini juga disebut alih kode.

\section{Bilingualisme}

Istilah bilingualisme (bilingualism) dalam bahasa Indonesia disebut juga kedwibahasaan. Secara harfiah sudah dapat dipahami apa yang dimaksud bilingualisme itu, yakni berkenaan dengan penggunaan dua bahasa atau dua kode bahasa. Dalam perspektif sosiolinguistik, bilingualisme diartikan sebagai penggunaan dua bahasa oleh seorang penutur dalam pergaulannya dengan orang lain secara bergantian. Untuk dapat menggunakan dua bahasa 
tentunya seseorang harus menguasai kedua bahasa itu. Pertama adalah bahasa ibu atau bahasa pertamanya dan yang kedua adalah bahasa lain yang menjadi bahasa keduanya (Piantari, dkk, 2011)

Fenomena pemakaian lebih dari satu bahasa ini disebut dengan bilingualism, kemampuan menguasai lebih dari satu bahasa disebut dengan bilingualitas, dan orang yang mengggunakan bahasa lebih dari satu bahasa disebut bilingual. Istilah bilingualisme dalam bahasa Indonesia disebut juga dengan kedwibahasaan. Dari istilah tersebut secara harfiah sudah dapat dipahami tentang definisi bilingualisme, yaitu berkenaan dengan penggunaan dua bahasa atau dua kode bahasa. Untuk dapat menggunakan dua bahasa tentunya seseorang harus menguasai dua bahasa itu. Pertama, bahasa itu sendiri atau bahasa pertamanya (B1) dan bahasa yang kedua (B2). Orang yang dapat menggunakan kedua bahasa itu disebut orang yang bilingual. Sedangkan kemampuan untuk menggunakan dua bahasa disebut bilingualitas.

Giussani, et al. (2007) mengatakan bahwa, "the term bilingual refers to an individual who uses two or more languages or dialects in his or her life, regardless of the context of use". Pendapat tersebut dapat diasumsikan bahwa istilah bilingual digunakan untuk individu yang menggunakan dua atau lebih bahasa atau dialek dalam hidupnya, terlepas dari konteks penggunaan. Berdasarkan pendapat tersebut dapat disimpulkan bahwa banyak Negara yang memiliki masyarakat yang bilingual.

Hal yang senada disampaikan oleh Fromkin, et al. (2011) bahwa "Bilingualism (or multilingualism) also refers to the situation in nations in which two (or more) languages are spoken and recognized as official or national languages". Pendapat tersebut berarti bahwa bilingualisme atau multilingualisme ditujukan untuk suatu negara yang menggunakan dan mengakui bahasa resmi dan bahasa nasional lebih dari dua/lebih.

Dalam era maju dan modern ini barang kali kita jarang menemukan masyarakat bahasa monolingual, masyarakat bahasa yang menggunakan satu bahasa disebut masyarakat monolingual. Akan tetapi, mungkin masih dapat kita temukan, misalnya di daerah-daerah terpencil. Ada juga kemungkinan masyarakat generasi lama yang karena satu dan lain hal tidak memiliki kesempatan belajar bahasa lain selain bahasa pertamanya atau bahasa daerahnya. Setelah menjadi generasi tua, mereka tetap menjadi masyarakat monolingual. Namun dalam kehidupan sehari-hari, ada pula masyarakat bilingual, masyarakat bahasa yang menggunakan dua bahasa. Setidaknya masyarakat yang menggunakan bahasa daerah dan bahasa Indonesia. Misalnya, masyarakat yang menggunakan bahasa Sunda dan bahasa Indonesia, bahasa Bengkulu dengan bahasa Indonesia, dan bahasa Jawa dan bahasa Indonesia.

Berdasarkan kemampuan penutur, bilingualisme dapat dipilah menjadi dua kategori, yakni bilingualisme setara dan bilingualisme majemuk. Bilingualisme setara terjadi pada penutur yang tingkat kemampuan menggunakan bahasanya sama, sedangkan bilingualisme majemuk terjadi pada penutur yang tingkat kemampuan menggunakan bahasanya tidak sama. Di dalam bilingualisme pemilihan bahasa ditentukan oleh unsur-unsur yang menjadi pertimbangan oleh penutur antara lain, di antaranya: (a) bahasa yang digunakan, (b) ranah (domain) penggunaan, dan (c) mitra tutur.

Jadi, seseorang dapat disebut bilingual apabila dapat menggunakan B1 dan B2 dengan derajat yang sama baiknya. Hal yang senada Lado (dalam Piantari, dkk, 2011) mengatakan bahwa bilingualisme adalah kemampuan menggunakan bahasa oleh seseorang dengan sama baik atau hampir sama baiknya, yang secara teknik mengacu pada pengetahuan dua buah bahasa bagaimanapun tingkatnya. Jadi, penguasaan terhadap kedua bahasa itu tidak perlu 
sama baiknya, kurang pun boleh. Sehingga dapat dikatakan bahwa seorang yang bilingual tidak perlu secara aktif menggunakan kedua bahasa itu, tetapi cukup kalau bisa memahaminya saja. Dalam mempelajari bahasa kedua, seseorang yang mempelajari bahasa asing, maka kemampuan bahasa asingnya atau B2-nya akan selalu berada pada posisi di bawah penutur asli bahasa itu.

Dari pembicaraan di atas, dapat disimpulkan bahwa pengertian bilingualisme akhirnya merupakan satu rentengan berjanjang mulai menguasai B1 (tentunya dengan baik karena bahasa ibu sendiri) ditambah dengan pengetahuan sedikit akan B2, dilanjutkan dengan penguasaan B2 yang berjenjang meningkat, sampai menguasai B2 itu sama baiknya dengan penguasaan B1. Jika bilingual sudah sampai di tahap ini, maka berarti seorang yang bilingual itu akan dapat menggunakan B1 dan B2 sama baiknya, untuk fungsi dan situasi apa saja dan di mana saja.

\section{Jejaring Sosial Path}

Jejaring sosial Path merupakan jejaring sosial dimana para pengguna dapat mengakses berbagai fitur aplikasi seperti fitur berbagi momen, fitur menggunggah foto dan video, fitur mengunggah lokasi, fitur berbagi musik, film dan buku, fitur tidur, fitur belanja, fitur mengirim pesan pada orang lain serta fitur berbagi komentar dengan sesama pengguna Path yang sebagian besar adalah remaja dan mahasiswa. Pada tahun 2013 Path banyak digandrungi oleh anak muda. CEO dan Cofounder Path Dave Morin, mengatakan angka pengguna aktif Path di Indonesia menjadi yang terbesar di dunia dengan jumlah mencapai 4 juta pengguna. (http://tekno.liputan 6.com)

Jejaring sosial digunakan para remaja untuk berlomba-lomba menjadikan identitas dirinya sebagai remaja yang "up to date" dengan cara menjadi pengguna aktif sosial media dengan check in place di tempat-tempat yang high class, foto-foto bersama teman-teman, genre music, film dan buku yang sedang popular. Penggunaan jejaring sosial Path telah menjadi sebuah rutinitas mahasiswa pada saat ini. Melalui jejaring sosial tersebut mahasiswa mampu berbagi mengenai segala aktivitas yang diunggahnya. Menurut Burhan Bungin fungsi cyber space telah mengembangkan dan mengacu pada pertukaran makna di dalam penggunaan media sosial. Kontak sosial yang terjadi di antara anggota masyarakat maya memiliki makna yang luas di dalam komunikasi mereka sehingga saling membangun makna dalam dunia intersubjektif mereka. (http://tekno.liputan 6.com)

\section{Metodologi Penelitian}

Pada penelitian ini, peneliti menggunakan pendekatan kualitatif dan metode studi kasus. Penelitian kualitatif bertolak dari filsafat konstruktivisme yang berasumsi bahwa kenyataan itu berdimensi jamak, interaktif, dan suatu pertukaran informasi sosial yang diinterpretasikan oleh individu-individu. Para peneliti kualitatif percaya bahwa kenyataan merupakan konstruksi sosial, bahwa individu-individu atau kelompok-kelompok memperoleh dan memberi makna terhadap kesatuan-kesatuan tertentu apakah itu peristiwa-peristiwa, orangorang, proses-proses atau objek-objek. Orang membuat konstruksi untuk memahaminya dan menyusunnya kembali sebagai sudut pandang persepsi dan sistem kepercayaan. Persepsi orang adalah apa yang dia yakini "nyata" padanya, dan apa yang mengarahkan kegiatan, pikiran, dan perasaannya. Penelitian kualitatif ditujukan untuk memahami fenomenafenomena sosial dari sudut atau perspektif partisipan. Penelitian kualitatif diarahkan lebih dari sekedar memahami fenomena tetapi juga mengembangkan teori.

Latar penelitian ini adalah budaya masyarakat Indonesia khususnya kaum muda yang cenderung menggunakan media sosial sebagai bagian dari interaksi komunikasi sehari-hari. Pada jejaring sosial Path yang terhubung kepada penulis, penulis melihat mayoritas adalah teman-teman dan orang-orang yang penulis kenal tidak hanya di dunia maya melainkan 
dikehidupan nyata sehari-hari yang terdiri dari teman semasa SMP, SMA serta teman semasa menempuh S1, S2, dan S3 serta teman-teman sejawat penulis sebagai dosen. Dimana penggunaaan bahasa Inggris sebagai bahasa kedua menjadi bagian dari sehari-sehari mereka.

Isi dari Path mereka adalah bagaimana mereka menggungkapan kegiatan dan perasaan mereka sehari-hari dan bagaimana mereka tanpa disadari menggunakan alih kode bahasa Inggris ke bahasa Indonesia atau sebaliknya sebagai bagian apa yang mereka tulis atau mereka tampilkan di lama Path mereka.

Dalam teknik pengumpuan data, penulis menggunakan metode observasi dan studi dokumen. Dalam hal ini observasi yang dimaksud adalah penulis mengamati semua akun Path yang terhubung dengan akun penulis atas nama Rosdiana Sidik untuk mengamati penggunakan alih kode yang digunakan oleh para pemilik akun. Untuk studi dokumen penulis juga menggunakan berbagai literatur yang mendukung penulis dalam melakukan penelitian ini. Dalam prosedur pengumpulan data, penulis menyimpan potongan status dan posting pada pengguna jejaring sosial Path yang terhubung dengan akun penulis yaitu Rosdiana Sidik. Dari hasil potongan tersebut penulis menganalisa data yang terkumpul dari data-data yang akan dilampirkan dalam penelitian ini.

\section{Hasil dan Pembahasan}

Pada hasil penelitian ini, penulis memiliki fokus pada kebahasaan yaitu alih kode pada pengguna jejaring sosial Path yang terhubung dengan akun penulis yaitu Rosdiana Sidik, maka penulis akan mendeskripsikan hasil-hasil temuan dari subfokus pada penelitian ini sebagai berikut:

\section{Jenis Alih Kode}

Alih kode yang ditemukan pada status Path adalah alih kode dalam bentuk kata, frasa, dan kalimat dalam bentuk alih kode antar kalimat dan dalam kalimat. Alih kode paling banyak ditemukan dalam kalimat dengan jenis alih kode antar kalimat. Hal tersebut ditunjukkan oleh tabel berikut ini:

Tabel 1. Jenis dan Bentuk Alih Kode

\begin{tabular}{ll}
\hline \multicolumn{1}{c}{ Jenis Alih Kode } & \multicolumn{1}{c}{ Bentuk Alih Kode } \\
\hline Alih kode antar kalimat (inter- & kalimat tunggal \\
sentential switching) & kalimat majemuk setara \\
& kalimat majemuk setingkat \\
\hline Alih kode dalam kalimat & Kata \\
& Frasa \\
\hline
\end{tabular}

Jenis Alih Kode antar Kalimat (inter-sentential switching)

Bentuk kalimat yang ditemukan pada alih kode meliputi bentuk kalimat tunggal seperti:

(1) "If there is any problem please tell to QC."

(2) "I'm sorry I can't be perfect."

Responden membuat status yang mengandung alih kode dalam bentuk kalimat tunggal. Kalimat tunggal dalam bahasa Inggris, dikategorisasikan ke dalam alih kode antar kalimat karena seluruh responden berbahasa ibu bahasa Indonesia, maka ketika responden menggunakan bahasa dalam kode lain, maka terjadi alih kode dari bahasa ibu ke bahasa asing, dalam hal ini bahasa Inggris. Kalimat tunggal dengan alih kode tersebut terjadi dalam bentuk pengalihan kode dari bahasa Indonesia ke bahasa Inggris.

Selain kalimat tunggal, kalimat majemuk juga banyak ditemukan dalam status yang beralih kode. Kalimat-kalimat majemuk pada status Path yang diteliti mencakupi kalimat majemuk 
setara yaitu kalimat majemuk yang terdiri dari dua klausa atau lebih dengan menggunakan kata penghubung seperti and, so, but, or dan kalimat majemuk bertingkat yang terdiri sari dua klausa atau lebih dengan salah satu klausa yang berfungsi sebagai anak kalimat.

(3) "To handle yourself, use your head; to handle other use your heart."

Alih kode dalam bentuk kalimat majemuk ini, tidak hanya muncul dalam bahasa Inggris saja, melainkan juga terdapat alih kode dalam bentuk campuran antara bahasa Indonesia dan bahasa Inggris, seperti:
(4) "Semangat dikejar deadline project UAS my classmates..\#not sleep."
(5) "Menembus sahur subuh ini, paper Sosiolingutics well done."

Alih kode pada data di atas menunjukkan bentuk kalimat majemuk yang merupakan campuran antara bahasa Indonesia dan bahasa Inggris. Pada data (4) dan (5) status diawali oleh klausa dalam bahasa Indonesia dan diakhiri oleh klausa dalam bahasa Inggris.

\section{Alih Kode dalam Kalimat}

Alih Kode dalam kalimat (intra-sentential switching). Sementara itu, alih kode yang terjadi dalam kalimat (intra-sentential switching) mencakupi alih kode dalam bentuk kata dan frasa. Frasa dan kata yang muncul dalam alih kode meliputi jenis kelas kata nomina, ajektiva, verba, dan adverbia. Kata-kata dengan alih kode tersebut muncul dalam bentuk: - kata tunggal seperti pada:
(6) "Note"
(7)"Badminthon time"

bagian dari kalimat, seperti:

(8) "Setelah sekian lama yang full team, akhirnya bisa full team.."

(9) "hahaha ampyun pakdeh budehhh so sweeettt deh"

(10)" Having fun with alay mall."

Pemunculan alih kode dalam bentuk kata menunjukkan bahwa kata atau istilah yang memang populer dimunculkan dalam bahasa Inggris, cenderung untuk dipertahankan tetap dalam bahasa Inggris. Kata-ka tetap gunakan dalam bentuk bahasa Inggris, karena oleh responden dianggap lebih tepat dinyatakan dalam bentuk bahasa Inggris. Selain muncul dalam bentuk kata, alih kode yang bersifat dalam kalimat juga muncul dalam bentuk: frasa nomina, frasa ajektiva, frasa verba, frasa preposisi, frasa adverbia. Frasa nomina mendominasi alih kode pada status Path. Frasa yang dialihkodekan adalah frasa yang sudah umum diungkapkan dalam bahasa Inggris. Hal tersebut menunjukkan penyebutan nama atau istilah seringkali lebih tepat disampaikan bahasa Inggris.

\section{Tema yang Muncul dalam Alih Kode}

Tema atau topik dalam status yang mengandung alih kode mencakupi tema-tema yang berkaitan dengan kehidupan sosial, akademik, dan kehidupan pribadi para mahasiswa pembuat status alih kode. Tema-tema yang muncul dapat dikategorisasikan sebagai berikut:

a. Kehidupan sosial (hubungan pertemanan, relasi dengan lawan jenis, keluarga, dan lingkungan pekerjaan).

b. Kehidupan akademi (kuliah).

c. Kehidupan pribadi (hobi, cita-cita, dan pandangan hidup).

Tema yang mendominasi adalah tema dalam kehidupan sosial yaitu pertemanan, relasi dengan lawan jenis. Pada tema tersebut, responden memunculkan alih kode untuk mengekspresikan perasaannya, seperti pada data berikut ini:

(2) "I'm sorry I can't be perfect." 
Pada alih kode dengan tema kehidupan akademik, responden banyak menggunakan alih kode untuk menyatakan pendapatnya mengenai mata kulih yang mereka ikuti, keadaan kelas, dan perasaan mereka terhadap perkuliahan yang mereka jalani, seperti:

(4) "Semangat dikejar deadline project UAS my classmates..\#not sleep."

(5) "Menembus sahur subuh ini, paper Sosiolingutics well done."

Status dengan tema yang berkaitan dengan kehidupan akademis, responden mengungkapkan perasaannya melalui bahasa Inggris. Responden mengalihkan kode bahasa yang digunakan dari bahasa Indonesia ke bahasa Inggris. Pada tema yang berhubungan dengan kehidupan pribadi, alih kode terjadi pada status yang berkaitan dengan hobi, kesukaan terhadap sesuatu, atau pandangan hidup, seperti:

(8) "Setelah sekian lama yang full team, akhirnya bisa full team.."

(9) "hahaha ampyun pakdeh budehhh so sweeettt deh."

(10)" Having fun with alay mall."

\section{Fungsi Alih Kode}

Alih kode pada Path yang terhubung dengan akun penulis yaitu Rosdiana Sidik yang diteliti memiliki beberapa fungsi.

\section{Mengungkapkan emosi atau perasaan}

Fungsi ini banyak ditemukan pada status yang diteliti. Hal tersebut dapat dilihat dari makna kalimat yang memiliki alih kode, bentuk-bentuk onologis dan morfologis kata pada alih kode, serta penggunaan kata-kata interjeksi yang menguatkan fungsi pengungkap emosi. Contoh-contoh alih kode yang mengungkapkan emosi atau perasaan adalah:

\section{(2) "I'm sorry I can't be perfect."}

\section{Menyampaikan makna secara lebih tepat}

Beberapa konsep makna dapat hanya dimiliki oleh bahasa-bahasa tertentu. Hal tersebut berkaitan dengan budaya tempat bahasa tersebut tumbuh dan berkembang. Konsep makna yang muncul dalam konteks semacam itu, seringkali agak sulit untuk diungkapkan dengan bahasa lain. Dalam keadaan semacam ini, alih kode biasanya muncul, seperti pada contohcontoh di bawah ini:

\section{(3) "To handle yourself, use your head; to handle other use your heart."}

Ekspresi mengungkapkan keinginan yang baik bagi orang lain atau perasaan kepada orang lain memiliki makna tertentu dalam bahasa lain, dalam hal ini bahasa Inggris. Jika diungkapkan dengan bahasa Indonesia, makna yang hendak disampaikan terasa janggal. Hal tersebut senada dengan pendapat yang disampaikan oleh para responden yang menyatakan bahwa dalam mengungkapkan emosi atau perasaan, mereka merasa lebih dapat menyampaikan apa yang mereka ingin sampaikan dalam bahasa Inggris. Beberapa responden juga menyatakan bahwa mengungkapkan perasaan dengan bahasa Inggris terasa lebih nyaman.

\section{Untuk menekankan makna}

Alih kode juga muncul ketika ada makna yang ingin ditekankan. Pada saat seseorang menggunakan bahasa dengan kode tertentu dan di dalam tuturannya terdapat makna yang ingin ditekankan, maka kode bahasa yang digunakan dapat berubah. Hal tersebut dapat dilihat pada data berikut:

(8) "Setelah sekian lama yang full team, akhirnya bisa full team.."

(9) "hahaha ampyun pakdeh budehhh so sweeettt deh"

(10)" Having fun with alay mall." 
Pengalihan kode dari bahasa Indonesia ke bahasa Inggris pada data di atas menunjukkan bahwa responden ingin menekankan makna tertentu sehingga makna yang sebenarnya sudah diungkapkan dalam bahasa Indonesia dialihkodekan ke dalam bahasa Inggris.

\section{Mengungkapkan identitas}

Sebagai anggota masyarakat yang bilingual atau bahkan mungkin multilingual, penggunaan alih kode dalam tuturan seringkali berfungsi sebagai pengungkap identitas atau solidaritas. Dalam hal ini, responden yang merupakan generasi muda adalah generasi yang terpajang dengan luasnya oleh bahasa asing sebagai bahasa Inggris. Terlebih lagi, responden menggunakan bahasa Inggris sebagai bahasa kedua dan bahas pergaulan sehari- hari. Oleh karena itu, penggunaan bahasa Inggris berfungsi sebagai pengungkap identitas. Hal tersebut dapat ditemukan pada beberapa status yang mengandung alih kode seperti berikut:

(4) "Semangat dikejar deadline project UAS my classmates..\#not sleep."

(5) "Menembus sahur subuh ini, paper Sosiolingutics well done."

Banyaknya alih kode yang terdapat pada jejaring sosial Path menunjukkan bahwa responden memiliki akses terhadap dua bahasa tersebut. Sehingga alih kode digunakan untuk menunjukkan identitas tersebut.

Seperti penjelasan pada bagian sebelumnya mengenai hasil pada penelitian ini, penulis terfokus pada penggunaan kebahasaan dalam hal ini alih kode yang digunakan para pengguna jejaring sosial Path yang terhubung pada akun penulis yaitu Rosdiana Sidik, penulis membagi ke dalam beberapa subfokus penelitian, yaitu:

\section{Jenis Alih Kode}

Seperti yang dijelaskan pada temuan penelitian, jenis alih kode yang ada pada hasil penelitian ini adalah Alih kode antar kalimat (inter-sentential switching) dan Alih kode dalam kalimat. Menurut Gumperz (dalam Piantari, dkk , 2011), terdapat dua jenis alih kode yaitu: situasional code switching (kecenderungan komunitas bilingual atau multilingual untuk menggunakan bahasa atau ragam bahasa yang berbeda pada situasi sosial yang berbeda) dan metaphorical code switching (kecenderungan dalam masyarakat bilingual atau multibahasa untuk beralih kode (bahasa atau ragam bahasa) dalam percakapan untuk membahas topik ke dalam wilayah percakapan lain).

Poplack seperti yang dikutip oleh Romaine (dalam Piantari, dkk, 2011) juga membedakan tiga tipe dari alih kode, yaitu:

a. Tag switching, is simply the insertion of a tag in one language in an utterance which is entirely in the other language, e.g. you know, I vmean, right?

b. Inter sentential switching, involves a significant amount of syntactic complexity and conformity to the rules of both languages; therefore speakers performing this kind of switching are usually fairly proficient in the participating languages.

c. Intra sentential switching refers to the switching that occurs inside the same clause or sentence which then contains elements of both languages. This type of switching appears to involve special principles governing how the syntax and morphology of both languages may interacted and consequently adopted only by bilinguals with high levels of fluency. (Piantari, dkk, 2011)

Poplack membagi alih kode menjadi tiga tipe, yaitu alih Tag, atau penyisipan Tag dalam satu bahasa dalam ucapan yang seluruhnya menggunakan bahasa lain. Tipe yang kedua adalah alih kode Intersentential, dalam tipe ini terjadi peralihan kalimat-kalimat yang cukup kompleks. Oleh karena itu, pada umumnya speaker mampu melakukan alih kode tersebut karena mahir dalam bahasa yang dipilihnya. Dan tipe yang ketiga adalah alih kode Intra sentential. Hal ini terjadi di dalam klausa yang sama atau kalimat yang kemudian 
mengandung unsur kedua bahasa. Tipe ini melibatkan prinsip-prinsip khusus yang mengatur bagaimana sintaksis dan morfologi kedua bahasa dapat berinteraksi.

Alih kode (code switching) adalah peristiwa peralihan dari satu kode ke kode yang lain. Misalnya penutur menggunakan bahasa Indonesia beralih menggunakan bahasa Inggris pada penelitian ini. Alih kode merupakan salah satu aspek ketergantungan bahasa (language dependency) dalam masyarakat multilingual. Dalam masyarakat multilingual sangat sulit seorang penutur mutlak hanya menggunakan satu bahasa.

\section{Tema yang Muncul dalam Alih Kode}

Tema pada temuan penelitian ini dibagi menjadi 3 tema besar, yaitu:

a. Kehidupan sosial (hubungan pertemanan, relasi dengan lawan jenis, keluarga, lingkungan pekerjaan).

b. Kehidupan akademi (kuliah).

c. Kehidupan pribadi (hobi, cita-cita, pandangan hidup).

Topik merupakan faktor yang dominan dalam menentukan terjadinya alih kode. Topik pembicaraan yang bersifat formal biasanya diungkapkan dengan ragam baku, dengan gaya netral dan serius dan pokok pembicaraan yang bersifat informal disampaikan dengan bahasa nonbaku, gaya sedikit emosional, dan serba seenaknya.

Hubungan antara budaya, masyarakat, individu, dan kode kemudian dikembangkan dalam strategi wacana (discourse strategies). Pada esainya, Gumperz (dalam Piantari, dkk, 2011), menyatakan bahwa "cognition and language, then, are affected by social and culture forces: the way we behave and express ourselves in relation to a linguistic code and the underlying categories of the code itself are open to external influence". Dari kutipan tersebut, dapat dikatakan bahwa kekuatan sosial budaya sangat berpengaruh pada kognisi dan bahasa yaitu pada cara seseorang berperilaku dan mengungkapkan kode-kode linguistiknya. Dalam rangka memahami pengaruh-pengaruh tersebut dibutuhkan teori umum komunikasi verbal yang mengintegrasikan hal-hal yang telah diketahui seperti tata bahasa, budaya, dan kesepakatan interaktif ke dalam kerangka konsep dan prosedur analitis yang menyeluruh.

\section{Fungsi Alih Kode}

Berdasarkan temuan pada penelitian ini, penulis pada Bab sebelumnya memaparkan, beberapa fungsi alih kode.

\section{Mengungkapkan emosi atau perasaan}

Dalam temuan yang dipaparkan dalam sebelumnya, emosi atau perasaan para penutur yang merupakan pengguna jejaring sosial Path yang terhubung dalam akun penulis Rosdiana Sidik tergambar jelas bahwa alih kode merupakan cara mereka berkomunikasi. Dengan alih kode bahasa Inggris mereka lebih mudah dalam menggungkapkan emosi atau perasaan daripada menggunakan bahasa Indonesia. Dengan begitu dapat dipahami dengan situasi perasaan atau emosi yang berbeda dan tidak biasa, maka alih kode dengan mudah dapat digunakan oleh penutur. Seperti yang diungkapkan oleh Romaine (dalam Piantari, dkk, 2011) bahwa "code switching is defines as the use of more than one language, variety, or style by speaker within an utterance or discourse, or between different interlocutors or situations". Sehingga dapat dikatakan bahwa alih kode dapat didefinisikan sebagai penggunaan lebih dari satu bahasa, variasi, atau gaya oleh pembicara dalam suatu ucapan atau wacana, atau antara lawan bicara atau situasi yang berbeda.

\section{Menyampaikan makna secara lebih tepat}

Dalam temuan penelitian, jelas bahwa pengguna jejaring sosial Path yang terhubung dengan akun penulis yaitu Rosdiana Sidik, alih kode memliki fungsi untuk menyampaikan makna 
lebih tepat. Mungkin dengan menggunakan bahasa asing dalam hal ini bahasa Inggris, penutur merasa lebih tepat sasaran. Makna penutur merupakan konsep penting dalam pragmatik Grice. Makna penutur tidak hanya memperbolehkan perbedaan antara 2 jenis makna (antara makna semantik dan makna pragmatik), tetapi juga terkait persepsi individu. (dalam Piantari, dkk, 2011)

\section{Untuk menekankan makna}

Dalam temuan penelitian, makna menjadi hal yang tidak terlepas dari penggunaan alih kode dalam jejaring sosial Path. Jejaring sosial sebagai media komunikasi menjadi begitu penting bagi penutur suatu bahasa sehingga fungsi prakmatik suatu bahasa menjadi hal yang ditekankan di sini. Seperti yang diungkapkan oleh Schriffin (dalam Piantari, dkk, 2011), pragmatik juga merupakan kajian hubungan tanda untuk diinterpretasikan. Jelas dapat dipahami bahwa penekanan makna menjadi tujuan penting bagi lawan tutur para pengguna jejaring sosial Path dalam menggungkapkan suatu hal.

\section{Mengungkapkan identitas}

Setiap orang memiliki indentitas tertentu, begitu halnya para pengguna jejaring sosial Path yang terhubung dengan akun penulis Rosdiana Sidik. Dengan menulis atau menggunggah suatu hal di jejaring sosial menunjukan identitas mereka dengan kegiatan mereka sehari-hari. Sebagai masyarakat sosial dengan segala dinamikanya, para penutur yang merupakan temanteman penulis menunjukkan identitasnya sebagai karyawan, dosen, mahasiswa ataupun ibu rumah tangga. Dengan alih kode yang digunakan mereka menunjukan identitas mereka dalam penggunaan alih kode bahasa Inggris dari bahasa Indonesia ataupun sebaliknya.

\section{Simpulan dan Saran \\ Simpulan}

Pada jejaring sosial Path yang terhubung dengan akun penulis yang diunggah oleh para pemilik akun memiliki dua jenis alih kode yaitu alih kode antar kalimat (inter-sentential) dan alih kode dalam kalimat (intra-sentential). Alih kode antar kalimat mendominasi pemunculan alih kode pada status Path mahasiswa. Kalimat-kalimat yang beralih kode tersebut muncul dalam bentuk kalimat tunggal, yang sepenuhnya berbahasa Inggris, kalimat majemuk setara dan bertingkat yang terdiri dari kalimat utuh berbahasa Inggris dan kalimat gabungan antara klausa berbahasa Inggris dan berbahasa Indonesia.

Alih kode dalam kalimat (intra-sentential switching) muncul dalam bentuk kata dan frasa. Nomina dan frasa nomina merupakan kelas kata dan kategorisasi frasa yang dominan muncul pada status Path. Kelas kata lain yang muncul pada alih kode pada jejarimg sosial Path adalah adalah ajektiva, verba dan adverbial. Sedangkan frasa yang muncul adalah frasa nomina, ajektiva, verba, adverbial, dan preposisi. Tema yang terdapat pada jejaring sosial Path yang beralih kode adalah tema yang berkaitan dengan kehidupan sosial (pertemanan, relasi dengan lawan jenis, keluarga, lingkungan sekitar, pekerjaan); kehidupan akademik (perkuliahan); kehidupan pribadi (hobi, cita-cita, pandangan hidup). Tema yang mendominasi pada status Path beralih kode adalah tema pertemanan dan relasi dengan lawan jenis. Tema status yang beralih kode tersebut menunjukkan fungsi alih kode. Fungsi yang ditemukan pada data adalah fungsi untuk mengungkapkan emosi atau perasaan, menyampaikan makna secara lebih tepat, menekankan makna tertentu, dan mengungkapkan identitas. Fungsi alih kode untuk mengungkapkan perasaan atau emosi mendominasi pada pemunculan alih kode pada jejaring sosial Path tersebut.

Kalimat, frasa, dan kata dalam alih kode yang mengungkapkan perasaan atau emosi merupakan kalimat, frasa, dan kata yang memiliki makna tertentu dalam bahasa Inggris. Oleh karena itu, sulit untuk mengalihkodekan beberapa ekspresi ke dalam bahasa lain, dalam hal ini bahasa Indonesia. Fungsi sosial memiliki peranan penting dalam pemunculan alih 
kode. Sebagai anggota masyarakat bahasa, seorang penutur tidak akan terlepas dari faktor sosial yang mempengaruhi penggunaan bahasanya.

\section{Saran}

1. Pemunculan alih kode pada tuturan pengguna bahasa menunjukkan kedwibahasaan penutur yang tentu saja sangat dipengaruhi oleh faktor-faktor sosial.

2. Fungsi sosial dari pemunculan alih kode tersebut belum dianalisis secara mendalam dalam penelitian ini, sehingga perlu ada penelitian lanjutan untuk meneliti faktor dan fungsi sosial dari alih kode.

\section{Daftar Pustaka}

Chaer, Abdul dan Agustina, Leonie. (2004). Sosiolinguistik: Perkenalan Awal. Jakarta: Rineka Cipta.

Crystal, David. (2003). English as a Global Language. Cambridge: Cambridge University Press.

Fromkin, Victoria, Rodman, R., and Nina, H. (2011). An Introduction to Language Ninth Edition. Wadsworth Publishing.

Giussani, et al. (2007). Intraoperative Language Localization in Multilingual Patienys and Glioms. Neurosurgery.

Hymes, Dell. (2003). Ethnography, Linguistics, Narrative Inequality. Taylor and Francis.

Nilep, Chad. (2006). "Code Switching" in Sociocultural Linguistics. Colorado Research in Linguistics, Vol. 19 June 2006. Boulder: University of Colorado.

Ohoiwutun, Paul. (2007). Sosiolinguistik Memahami Bahasa dalam Konteks Masyarakat dan kebudayaan. Jakarta: Kesaint Blanc.

Piantari, Lusi Lian, dkk. (2011). Alih Kode (Code-Switching) Pada Status Jejaring Sosial Facebook Mahasiswa. Jurnal Al-Azhar Indonesia Seri Humaniora, Vol. 1 No. 1 Tahun 2011.

http://tekno.liputan 6.com 